\title{
EM NOME DO PAI \\ Justificativas do voto dos deputados federais \\ evangélicos e não evangélicos na abertura do impeachment de Dilma Rousseff*
}

\section{Reginaldo Prandi}

Universidade de São Paulo (USP), São Paulo - SP, Brasil. E-mail: rprandi@uol.com.br

\section{João Luiz Carneiro}

Faculdade de Teologia Umbandista (FTU), São Paulo - SP, Brasil. E-mail: joaoluizcarneiro@gmail.com

DOI: http//dx.doi.org/10.17666/339603/2018

\section{Introdução}

Em 17 de abril de 2016, por 367 votos favoráveis e 137 contrários, a Câmara dos Deputados aprovou a admissibilidade do processo de impeachment da presidente Dilma Rousseff, processo que a partir daí seguiu para o Senado para a decisão final que a tirou da presidência. Dos 513 deputados, dois estiveram ausentes e sete se abstiveram.

* Agradecemos ao Departamento de Taquigrafia, Revisão e Redação da Câmara dos Deputados pela disponibilizaçấo da transcrição integral da sessão de votação da admissibilidade do impeachment da presidente Dilma Rousseff. Agradecemos também a Thiaquelliny Teixeira Pereira pela leitura crítica dos originais e a Renan William dos Santos pelo suporte técnico para o processamento dos dados e por suas valiosas sugestóes.
Dos 81 deputados que compóem a Frente Parlamentar Evangélica, também conhecida como Bancada Evangélica, um não compareceu e 75 votaram a favor da admissibilidade do impeachment. No conjunto dos demais 432 deputados, que não fazem parte desse grupo evangélico, o número de votos favoráveis ao processo de impeachment foi de 292, com uma ausência registrada. Em termos relativos, o encaminhamento do processo de admissibilidade do impeachment da presidente Dilma pelos votantes foi de $93,8 \%$ entre os evangélicos e de $67,7 \%$ entre os não evangélicos; no total, $71,8 \%$. Com uma porcentagem tão expressiva, os evangélicos marcaram sua diferença.

A sessão de votação aberta no plenário da Câmara, que o país pôde assistir ao vivo por diversos canais de televisão, durou quase dez horas, das quais seis foram tomadas pela votação propriamente dita. Ela foi precedida por exaustivas exposiçóes dos motivos a favor e contra e, no dia da votação, 
cada deputado deveria dar seu voto ao microfone instalado no centro do plenário. Tendo o país como plateia, quase nenhum deles deixou de expor, em poucas palavras e em tempo curto, premido pela mesa diretora da Câmara, os motivos e razóes de seu voto.

O presente trabalho se vale da transcrição e posterior codificação dessas breves justificativas para tentar entender, ou minimamente sistematizar, os diferentes valores e concepçóes políticas e culturais que eventualmente podem nortear o desempenho parlamentar dos representantes do povo na Câmara dos Deputados, especialmente num momento de crise política. A pergunta central diz respeito ao lugar da orientação religiosa no processo em questão, sobretudo quando um grupo numericamente expressivo se mostra publicamente organizado em uma bancada religiosa, a Bancada Evangélica. Supóe-se que, nesse caso, a orientação valorativa do exercício político, ou do discurso que lhe serve de moldura, pode sofrer influência da filiação religiosa por escolha, que implica a comunhão de valores marcadamente internalizados (Camargo, 1971).

Mesmo no caso dos parlamentes que se destacam por sua identidade religiosa, é certo que os mais diversos sentidos, oriundos de outras esferas sociais (como a econômica e a intelectual, por exemplo), podem pautar sua conduta. Assim, não se trata de reduzir a atuação desses parlamentares à mera reprodução automática e uniforme de determinadas crenças religiosas, mas de mensurar, de alguma maneira, o peso que essa orientação teve em um momento específico de enorme relevância para o contexto político nacional, o processo de impeachment de Dilma Rousseff. Nesse sentido, e ainda para evitar mal-entendidos, vale destacar que determinada atuação ou discurso só foi qualificada aqui de religiosa na medida em que apela para "crenças, ações e instituições que assumem a existência de entidades sobrenaturais com poder de ação, ou poderes impessoais ou processos dotados de propósito moral" (Bruce, 2011, p. 112).

A Bancada Evangélica reúne congressistas ligados a diferentes igrejas evangélicas, tanto do ramo histórico ou de missão como do pentecostal e neopentecostal, que atuariam em conjunto para aprovar ou rejeitar legislação de interesse religioso e pautar diversas discussóes no parlamento brasileiro. Seu nome oficial é Frente Parlamentar Evangélica, mas essa frente é correntemente chamada de Bancada Evangélica pela mídia, pela literatura científica, pelo Departamento Intersindical de Assessoria Parlamentar (Diap) e por seus próprios membros. ${ }^{1}$

Vale dizer que os membros da Bancada Evangélica, que além de pertencerem a diversos partidos, participam de diferentes igrejas que competem inclusive entre si no mercado religioso, não votam necessariamente em uníssono, podendo manifestar em certas situaçóes baixa coalizão. No entanto, quando se trata de temas afeitos à moral sexual e outras questôes da intimidade, tendem a votar em bloco, apesar de algumas divergências observadas mesmo nessa área (Prandi e Santos, 2017). No julgamento da instauração do impeachment de Dilma Rousseff, uma pauta emblematicamente política, a Bancada Evangélica, com apenas cinco votos destoantes, votou em bloco a favor da admissibilidade. Mais que isso: sua posição foi mais incisiva que a da parcela dos deputados não evangélicos. Mostrar o diferencial da religião na base discursiva que justificou tal posição é o objetivo principal do presente trabalho.

\section{Os evangélicos na política}

Antes de se avançar no assunto principal deste artigo, algumas palavras sobre os evangélicos na política brasileira se fazem oportunas. Como aponta Antônio Gouvêa Mendonça (2008, p. 67), desde a Segunda República "alguns poucos protestantes históricos ingressaram na política, fazendo parte da Constituinte de 1934". Já nessa época, os políticos evangélicos tinham como características gerais "posiçôes de direita" e propostas "defensoras do status quo" (Mendonça, 2008, p. 67). O ingresso expressivo na política partidária de representantes de igrejas evangélicas, contudo, só se dá a partir da Assembleia Constituinte, eleita no final de 1986 (Pierucci, 1996).

Em grande parte, essa abertura à participação política mais ampla de outras religióes é fruto da secularização que retirou do catolicismo sua histórica prerrogativa de religião social, cultural e politicamente dominante. Essa mudança fez a Igreja Cató- 
lica refluir "para um âmbito menos 'público' e mais 'religioso", abrindo "as brechas para que 'o sopro do profano' alcançasse largamente a cultura” (Rosado-Nunes, 2004, p. 23-25). Se durante um longo período a sociologia da religiáo no Brasil podia ser pensada como uma sociologia do declínio da Igreja Católica em termos de perda de seguidores, os quais têm abandonado o catolicismo para aderir a outras religiōes ou se afastar de todas elas (Pierucci, 2008a), hoje já se pode pensar em ampliar esse escopo para tentar enxergar as consequências dessa perda progressiva de importância (Prandi, 2008).

Representando mais um daqueles típicos paradoxos das consequências dos quais fala Weber (2004), a avassaladora expansão do pentecostalismo veio como uma consequência não desejada e imprevista da adesão moderna e intencional do catolicismo ao processo de secularizaçấo (Pierucci, 1998; Mariano, 2011), sobretudo nas áreas urbanas em rápida expansão demográfica, garantida pela migração do campo para a cidade. O empenho do catolicismo de se recolocar no mundo contemporâneo, de se atualizar, já em curso após o final da segunda guerra mundial (Prandi, 1975), culminou com as reformas implementadas a partir do Concílio Vaticano II (Prandi e Santos, 2015). Tal movimento deixou para trás parcelas da população que se sentiram órfấs da velha e tradicional religião que melhor atendia a seus modos de viver e sentir o mundo.

Em contrapartida, outras religióes, que à época abriam seus caminhos em território católico, estavam prontas para adotá-los. A via secularizante trilhada pelo catolicismo facilitou, assim, o crescimento de grupos religiosos diversificados, especialmente os dos pentecostais, assim como outros grupos menores em termos de seguidores, mas de grande importância cultural, com destaque para os espíritas e afro-brasileiros (Camargo et al., 1973, pp. 36-37; Prandi, 2012; Carneiro, 2014).

Enquanto o prestígio social, o reconhecimento como fonte da identidade brasileira e as referências culturais ainda pertenciam - como continuam de certo modo pertencendo - ao catolicismo, o espaço do já crescido pentecostalismo continuava restrito ao templo, à casa e, timidamente, à praça onde alguém, visto com maus olhos pelos que por ali passavam, pregava em busca de conversos. Socialmente, a religião pentecostal era encarada como uma crença tolerada (favor que o espiritismo e a umbanda sequer alcançavam), de qualidade duvidosa, ocupando inicialmente espaço em garagens, armazéns e decrépitos cinemas ociosos.

Apesar de ter perdido grande parte do poder de influir na sociedade, a Igreja Católica ainda dava o tom. Se é verdade que ela abrira espaço para o crescimento pentecostal, também é certo que ela não estava morta. Absolutamente. Movimentos católicos robustos como o das comunidades eclesiais de base e, depois, o da renovação carismática (Prandi, 1998; Carranza, 2000), este quase irmão católico da religião pentecostal, em termos de doutrina e rituais, atestam o fôlego do catolicismo (Prandi, 2008). Definitivamente, o pentecostalismo não tinha ainda seu lugar garantido. Era preciso lutar por ele em outras frentes. ${ }^{2}$

Depois da presença de poucos precursores, a chegada definitiva dos evangélicos ao Congresso Nacional deveu-se muito à preocupação de grande parte de suas igrejas em se defender, no momento em que se escreveria uma nova Constituição para o país, de uma eventual devolução de privilégios antigos e exclusivos ao catolicismo (Pierucci, 1996). Temiam, sobretudo, a legitimação pela lei maior de avanços sociais que ocorriam à margem da religião em benefício de grupos excluídos e seus movimentos sociais, que desenhavam novos costumes e valores. Os evangélicos se dispuseram a agir na feitura da lei para evitar, por exemplo, que fosse inscrita na Carta Magna do país a defesa dos homossexuais, dos comunistas, das feministas, da liberalização do aborto, do uso de drogas e outros temas contrários à moral pregada por suas igrejas. Eram acompanhados pelos minguados deputados que se apresentavam explicitamente como representantes do catolicismo.

De início, os evangélicos recém-ingressados na política partidária como grupo expressivo se acomodaram num jogo de toma-lá-dá-cá com o Poder Executivo que beneficiou as igrejas, aquinhoadas que foram com concessóes de canais de televisão e rádio, e com sua inclusão no financiamento de projetos sociais conduzidos por entidades religiosas (Mariano, 2005). Testaram sua força eleitoral na eleição de Collor a presidente da República (Pie- 
rucci e Mariano, 1996) e, adiante, notadamente os evangélicos de igrejas pentecostais e neopentecostais (porque os tempos agora já eram outros), fizeram do voto das massas convertidas moeda de troca que os gabaritou para interferir em pautas de projetos sociais do governo e programas político-eleitorais de candidatos e partidos que tratam da conduta humana privada (Costa, 2014).

Nessa "hora de construir catedrais", expressão cunhada por um bispo neopentecostal (Pierucci, 2013, p. 58), os evangélicos criaram partidos próprios e alcançaram postos, secretarias, ministérios e governos, em um frutífero desempenho (Steil, 2001; Oro, 2006; Campos, 2006; Machado e Burity, 2014). Das cadeiras legislativas se alçaram para ocupar assentos no governo. $\mathrm{O}$ passo seguinte, atual e ainda incerto, consiste em enfrentar a necessidade de normatizar, planejar e gerir uma sociedade que não precisa mais da religião "para nada essencial ao seu funcionamento", embora dela possa fazer uso para dar respostas a dificuldades e interesses do indivíduo, sobretudo quando meios mais eficazes de solucionar tais problemas não se mostram equitativamente acessíveis aos diferentes estratos de uma sociedade baseada na desigualdade de renda, oportunidades e benefícios (Prandi, 1996). Não à toa, nos dias de hoje, quanto menores os índices de desigualdade e maiores os níveis de segurança existencial, menor é a frequência aos locais de culto e menor é a importância atribuída pelos fiéis aos cultos religiosos nos mais diferentes países (Norris e Inglehart, 2006; 2007).

A impermeabilidade estrutural do conjunto da sociedade a diretrizes dogmáticas sagradas e indiscutíveis é um desafio que qualquer religião com ambiçôes totalizantes tem de enfrentar no mundo ocidental moderno. Além de se ver obrigada a lidar com diferentes concepçóes do que seja a natureza e, por conseguinte, o natural (Hervieu-Léger, 2003), as religióes são compelidas a adequar seus valores baseados na tradiçáo - valores que defendem como naturais e, por isso, eternos e imutáveis - a situaçóes de vida que se encontram num estado de mudança permanente e que oferecem vantagens e bens por todos desejados. A mesma necessidade de adaptação se impóe na esfera política, na qual as religióes, inclusive as pentecostais, "precisam necessariamente se submeter à lógica dos poderes públi- cos, ao domínio da lei e às instituiçóes, aos direitos e deveres democráticos" (Mariano, 1999, p. 110).

Com isso, apesar de toda a tensão que a presença dos evangélicos na política provoca em alguns círculos, o diagnóstico de que eles possam estar causando algum tipo de crise na democracia ou mesmo na laicidade estatal não se sustenta. Ao mesmo tempo que as lideranças religiosas precisam aceitar "a autonomia dos governos democraticamente eleitos, sem exigir o privilégio de prerrogativas constitucionais para autorizar ou vetar políticas públicas" (Casanova, 2010, p. 8), as instituições políticas democráticas também são capazes conviver com a expressão publica de valores religiosos e a formação de organizaçóes e movimentos políticos religiosos "sempre que não sejam violadas normas democráticas e sejam seguidas as leis" (idem). Ou seja, a atuação religiosa na arena política pode até ter um viés tradicionalista, mas "as posiçóes conservadoras dos evangélicos em temáticas como direitos sexuais e reprodutivos e combate à homofobia não devem ser necessariamente compreendidas como ataques à democracia" (Machado e Burity, 2014, p. 612). A partir das casas legislativas as igrejas têm a possibilidade de ao menos atrasar mudanças sociais que negam seus princípios moralizadores, mas seus representantes têm de trabalhar também com temas completamente alheios à religião e aos costumes (Prandi e Santos, 2017). É o caso emblemático em que cabe ao parlamento aprovar ou rejeitar a iniciativa de afastar uma presidente da república do cargo para o qual ela foi eleita pela maioria, sob a alegação de má prática administrativa, meramente administrativa. A decisão do legislador certamente será conduzida mais por acordos, alianças partidárias e penhora de apoios, e menos por convicçóes pessoais, inclusive as religiosas. Nesses momentos de decisão, porque a nossa sociedade é secularizada, os interesses político-partidários reais falam mais alto do que a religião, embora, ao justificar sua escolha, o representante de denominação ou movimento religioso tenha a liberdade de legitimar sua posição atendendo expectativas de quem deve representar, seus eleitores. No caso, eleitores supostamente religiosos.

Trocando em miúdos, o deputado vota por acordo de interesse político-partidário - basta lem- 
brar, por exemplo, que o líder de uma das maiores instituiçóes pentecostais, Edir Macedo, já figurou tanto como cabo eleitoral de Dilma quanto como defensor de seu impeachment -, mas pode usar uma justificativa com outra referência que agrade mais a seu eleitorado. A religião, como toda tradição, pode ser usada como fachada, sem que ela seja a fonte verdadeira da razão de açóes e barganhas postas no jogo. Na condição de neófitos em política, os pentecostais podem, ao tomar uma posição, até parecer mais radicais que seus parceiros que não representam especialmente nenhuma religião, mas, em última instância, ainda é o jogo profano da política partidária que continua dando as cartas.

\section{O voto justificado}

No rito do impeachment, cada deputado precedia seu voto por um curto discurso que fundamentava sua decisão. Alguns exemplos dados a seguir são bem ilustrativos, ainda que não incluam todas as razóes apresentadas.

Constante nos discursos é a referência à base eleitoral a que o deputado certamente procura responder. "O meu lugar", que pode ser uma ou mais cidades, um Estado ou uma de suas regióes, aparece na maior parte das vezes em meio a outras justificativas, como nos discursos seguintes, mas também foi citado como justificativa única.

Em respeito aos homens e mulheres do Maranhão que me fizeram deputado federal e pelo desenvolvimento do nosso país, eu voto "sim", sr. presidente (Hildo Rocha, PMDB-MA).

Pelo meu querido Estado do Acre; pelos peemedebistas, que sempre me acompanharam; pela democracia; pelo futuro deste país para nossos filhos e nossos netos, eu voto "sim" (Flaviano Melo, PMDB-AC).

Sr. presidente, é importante que as pessoas saibam que eu vim das Minas Gerais, e ninguém vem das Minas Gerais à toa. O Brasil caminha para onde o povo mineiro aponta. Por isso, sr. presidente, o meu voto é "sim", é "sim" e é “sim” (Marcelo Aro, PHS-MG).

Sr. presidente, pelo Brasil, por todas as cidades do Rio de Janeiro, pelo eleitor que me colocou aqui, pelo trabalhador desempregado, pela minha família, eu digo: "O verde de teu mar, oh, Angra dos Reis! A luz de teu luar, oh, Angra dos Reis! O brilho do teu sol, oh, Angra dos Reis!" "Sim" pelo impeachment da Dilma! (Fernando Jordão, PMDB-RJ).

Valores universais comuns que lastreiam muito do comportamento na vida cotidiana das pessoas, como família, vida, esperança e fé, foram fartamente usados pelos deputados, que de certo modo se puseram na posição de prestar contas a seu eleitorado. Desses temas, a família é aquele a que a população brasileira, em pesquisa de opinião, atribui a maior importância em suas vidas. Pesquisas do instituto Datafolha, ao longo do tempo, mostraram que a população brasileira situa a família no posto mais elevado, quando comparada com trabalho, estudo, religião, dinheiro, lazer e casamentos. Para 2015, a taxa dos que atribuem à família o grau de importante ou muito importante em suas vidas foi de $99 \%$, valor muito próximo aos obtidos em pesquisas similares realizadas em 1998 e 2007 (Janoni, 2016). Na votação da admissibilidade do impeachment, foram citadas tanto a família do deputado como a família de um lugar, do Brasil, ou simplesmente "a família", como conceito.

Sr. presidente, pela minha família, pelos meus filhos, pelo povo do Estado do Rio de Janeiro e pela população de Itaguaí, ordeira e trabalhadora, eu voto "sim" (Alexandre Vale, PR-RJ).

Presidente, pelo resgate da esperança do povo brasileiro, pela reconstrução do nosso país, mas, sobretudo, em defesa da vida, da família e da fé, voto "sim" (Erivelton Santana, PEN-BA).

$\mathrm{Na}$ dificuldade, nós não podemos nos eximir da responsabilidade. Consciente da minha decisão, em nome da minha família, do povo de Juazeiro, do Crato, de Barbalha, da maioria do Cariri e da maioria do Ceará, em homenagem 
ao povo nordestino e respeitando a decisão do povo brasileiro, o meu voto é "não" (Arnon Bezerra, PTB-CE).

Pela minha família, minha esposa, meus filhos, pelas famílias brasileiras, pelas crianças do Brasil, pela minha Santa Rosa, meu povo do Rio Grande, pelo Brasil, é "sim", sr. presidente! (Osmar Terra, PMDB-RS).

Sr. presidente, sras. e srs. deputados, em respeito ao povo de Alagoas, em defesa da Constituição Federal, em nome da memória do meu avô, minha maior referência, o saudoso Menestrel das Alagoas, Teotônio Vilela, para renovar a esperança do povo brasileiro, eu voto "sim" (Pedro Vilela, PSDB-AL).

Justificativas pressupostas na atividade política tiveram igualmente seu lugar em muitas declaraçóes de voto, mas de modo geral combinadas com outros motivos. A palavra "democracia" é frequente; o termo "república", entretanto, foi raramente lembrado. Evidentemente, a mesma justificativa pôde ser usada para legitimar o voto a favor, o voto contra e mesmo a abstenção. Temas como a ética e a moralidade na vida pública também não podiam estar ausentes, combinando-se frequentemente com outros motivos.

Sr. presidente, pelos milhares de mineiros que me confiaram a sua representação aqui nesta casa, mineiros da minha querida Divinópolis; mineiros da minha terra natal, Nova Serrana; de Formiga; de Arcos; pelo povo de Belo Horizonte; na expectativa, sr. presidente, de que este seja o início de uma pauta ética, que traga para a vida pública a decência e a moralidade de volta; pela minha família, pelos meus filhos, pela minha esposa, pela minha neta, pelo meu pai, hoje ausente, mas sempre presente na minha vida, pela minha mãe, dona Maria, os quais me ensinaram os valores que norteiam a minha vida pública, pelos meus irmãos, eu voto "sim", sr. presidente (Jaime Martins, PSD-MG).

Muitos deputados usaram como razão do voto sua avaliaçáo do governo da presidente. Os que votaram pela admissibilidade evidentemente listaram o que consideravam fracasso da política da presidente e de seu partido, referindo-se sobretudo aos efeitos da crise econômica. Outros, ao votarem contra o processo de impeachment, referiram-se a obras, programas e iniciativas consideradas positivas. Referências à esquerda, ao socialismo e ao comunismo foram, por sua vez, usadas para mostrar que a presidente deveria ser afastada.

Sr. presidente, sras. e srs. deputados, em um momento este país escolheu a bandeira vermelha, mas viu que errou e quer novamente o verde-amarelo, a ordem e o progresso. Esse povo que está aí fora não veio da Venezuela, não veio da Coreia do Norte. Eu queria aqui, em nome da minha família, em nome da minha região noroeste do Estado de São Paulo, da minha cidade natal, votar "sim" e registrar que William Woo, que é suplente, se estivesse aqui, também votaria "sim", por um Brasil mais forte, um Brasil independente, um Brasil sem corrupção (Fausto Pinato, PP-SP).

Referências a Deus e a certas igrejas e denominaçóes religiosas não podiam faltar numa casa legislativa em que quase um quinto se apresenta como representante de algum segmento religioso, evangélico na esmagadora maioria.

Feliz é a nação cujo Deus é o Senhor! Em defesa da vida, da família, da moral, dos bons costumes, contra a corrupção e não desistindo do Brasil, meu voto é "sim" (Pastor Eurico, PHS-PE).

Sr. presidente, sem medo de ter esperança e com a convicção de que a Constituição Federal ampara esta sessão; pelo povo brasileiro; pelo Distrito Federal; pela nação evangélica e cristã e pela paz de Jerusalém, eu voto "sim" (Ronaldo Fonseca, PROS-DF).

Srs. deputados, sr. presidente, povo brasileiro, em primeiro lugar, eu quero agradecer a Deus a oportunidade de ser eleito por um Estado tão amável, tão maravilhoso como Minas Gerais. Neste Estado, nasceu uma 
pessoa que admiro muito, que é o apóstolo Valdemiro Santiago, e aquela Igreja maravilhosa me ajudou neste trabalho. Quero agradecer também à minha esposa, à minha filha, que vêm me dando muita força; à minha mãe; à minha tia Eurides, que cuidou de mim quando pequeno; à minha tia Geo, que me ensinou a educação. Eu quero agradecer ao povo brasileiro e dizer, neste instante, contra a corrupção, contra a roubalheira, contra a safadeza, eu sempre lutei por novas eleiçóes. Neste momento, para que o brasileiro tenha uma nova esperança de dias melhores, de prosperidade, eu voto "sim" (Franklin Lima, PP-MG).

Glória a Deus! Sr. presidente, todos aqui ouviram eu falar "Fora, Dilma!", "Fora, Michel Temer!", "Fora, Eduardo Cunha!", "Fora, Rede Globo", mentirosa, que fica difamando pessoas. Vocês podem ser grandes aos olhos do homem, mas, para Deus, vocês são pequenininhos. Em nome do Senhor Jesus, eu profetizo a queda dos senhores a partir de hoje. E venho dizer aqui, pelos militares das Forças Armadas que estão sendo sucateados há anos, pelos militares da segurança pública que estão morrendo todos os dias, pelos militares que estão agora, inativos e pensionistas, sem salário, "Fora, Pezão!”, “Fora, Dornelles!”. Chega de corrupção! O meu voto é "sim". Glória a Deus! Feliz a nação cujo Deus é o Senhor (Cabo Daciolo, PTdoB-RJ).

Em meio aos deputados evangélicos, os raros deputados católicos carismáticos engrossaram o coro dos que invocaram sua filiação religiosa ao votar.

Sr. presidente, fui eleito por paranaenses que acreditam no resgate da moralidade na política. Fui eleito pelo projeto de fé e política da renovação carismática católica no meu Estado do Paraná. Pela minha família, pela minha filha, pela minha esposa, pelo povo do Paraná, tenho orgulho em dizer: terra da Lava-Jato, avante! Polícia Federal! "Sim” ao impeachment (Diego Garcia, PHS-PR).
Sr. presidente, pelos valores que herdei dos meus pais, e que procuro repassar aos meus filhos; pela gratidão que tenho à Renovação Carismática Católica, à Canção Nova e aos demais movimentos que me ajudaram a me livrar das drogas; pelos milhóes de brasileiros que vivem hoje nas drogas e não têm ajuda; para honrar os belorizontinos, os mineiros, os brasileiros nesta Terra de Santa Cruz, o meu voto é "sim". E o voto do meu suplente, Euclides, também seria "sim", sr. presidente (Eros Biondini, PROS-MG).

Houve quem, ao votar, criticasse o uso do nome de Deus.

Sr. presidente, primeiro, quero deixar registrado que nunca em minha vida, em um espaço tão curto, eu ouvi tantas vezes o nome de Deus ser usado em vão, como se fosse um panfleto. Em segundo lugar, em respeito ao voto popular, em respeito à democracia, eu voto "não", sr. presidente. Golpe não! (Luiz Sérgio, PT-RJ).

A crítica ao uso do nome de Deus se somou à crítica a referências à família e outras razões que pareceram estranhas a uma sessão parlamentar que abria o processo de afastamento da presidente.

Sras. parlamentares, srs. parlamentares, ouvindo com atençáo os oradores que me precederam, eu observei, com espanto, que a maioria dos deputados que apoiam o impeachment o fazem invocando os seus familiares, os aniversários, a situação das estradas, as coisas mais diversas, inclusive o nome de Deus. Náo aludem ao crime de responsabilidade, que seria a causa constitucional para o impeachment, porque esse crime não existe. A presidenta Dilma não cometeu crime nenhum. Ela é uma mulher decente, íntegra, honesta, que está sendo vítima de uma grande injustiça. Peço aos senhores que me ouçam como eu os ouvi. Eu os ouvi mencionando todas as razões. Eu quero falar, em nome da democracia, em homenagem a todos os que estão nas redes sociais e nas ruas, lutando pela democracia e contra o golpe, que voto contra o golpe, 
contra os golpistas, contra Eduardo Cunha, contra Michel Temer (Margarida Salom, PT-MG).

Os discursos que, como se viu, têm conteúdos muito diversificados, não necessariamente políticos, surpreenderam mídia e telespectadores que acompanharam a sessão. No dia seguinte à votação, em matéria na Folha de S. Paulo, o diretor de pesquisa do Instituto de Pesquisa Datafolha escreveu: "O Datafolha nem precisou tabular - mençóes a Deus e à família dominaram ostensivamente a votação pela abertura do processo de impeachment na Câmara dos Deputados no último domingo" (Janoni, 2016). De fato, como se verá adiante, a família ficou em terceiro lugar, mas, contrariamente ao que pode sugerir o título do presente trabalho, Deus mereceu apenas o décimo primeiro posto. Vale dizer que o apelo a expressóes, citaçóes e valores de origem religiosa no momento do voto não foi prerrogativa evangélica, podendo estar presente no discurso de qualquer deputado, independentemente de qual fosse sua religião, mas pesou no caso de parlamentar publicamente comprometido com a religiáo. De todo modo, no conjunto, as justificativas se mostraram menos afeitas à política e mais condizentes com a tradição, em reiteradas referências a "meu lugar", "minha gente", "minha família”, "meu grupo".

\section{Indicadores e dimensóes da razáo do voto}

Apesar da grande diversidade de justificativas, muitos motivos se repetem e se combinam. Usando-se as notas taquigráficas da sessão de votação da admissibilidade do impeachment da presidente Dilma Rousseff, ocorrida no dia 17 de abril de 2016 na Câmara dos Deputados, construiu-se para este artigo uma extensa primeira lista dessas justificativas, depois reduzida àquelas citadas ao menos por sete deputados. Em muitos casos, bastou uma palavra para definir uma justificativa do voto: democracia, constituição, Deus. Em outros, são várias as palavras ou expressóes que podem se referir a um mesmo motivo ou orientação que embasa, verdadeiramente ou não, a escolha do deputado.

Quando um deputado diz que vota em nome de sua cidade, qualquer que seja ela, de seu Esta- do ou região, ou ainda quando fala do povo de sua cidade, ele está se referindo à sua base eleitoral, o que nos permitiu juntar todas essas respostas em um único item. Não faltou quem citasse diferentes nomes de pessoas que podem ser reunidos em uma categoria que contempla políticos famosos e personagens históricos, independentemente de seus atos e posiçóes ideológicas. Foram tomadas como indicadores de "mau governo" as referências à política de recessão e inflação, à incompetência da presidente, à condução das políticas de estado que teria quebrado o país, aos crimes de improbidade administrativa e de responsabilidade fiscal, às pedaladas fiscais e aumento de falências e inadimplência das empresas etc. Analogamente, representam o "bom governo", seja o da presidente Dilma, seja o do PT, referências a políticas públicas, ao aumento de postos de trabalho, a programas sociais como o Minha Casa, Minha Vida, o Bolsa Família e o Fies.

$\mathrm{Na}$ composição de cada grupo de justificativa, o voto "sim" ou "não" foi levado em consideração. A mensuração da associação entre a justificativa e o voto representa uma outra etapa da pesquisa. Juntando motivos e razóes que apontam para dimensóes e aspectos assemelhados, chegou-se ao final a 26 itens. Para cada deputado, construiu-se um registro contendo suas qualificaçóes (partido, unidade da federação, gênero), seu voto e sua citação ou náo de cada um desses 26 itens identificados na transcrição da votação. A Tabela 1 oferece a lista de termos, nomes e expressóes que foram usadas como indicadores para definir cada uma das variáveis, que estão apresentadas na mesma tabela segundo a ordem decrescente do número de deputados que citaram indicadores da variável ou justificativa.

Criou-se também uma variável que indica se o deputado pertence ou não à Bancada Evangélica, usando-se para isso informaçóes do Diap (2014) e de variados sites da internet, inclusive os produzidos pela Câmara dos Deputados, pelos partidos, pela Bancada Evangélica e pelos próprios deputados, além de notícias veiculadas na internet.

O resultado da votação foi evidentemente o que mais atraiu a atenção do país, ao mesmo tempo que as justificativas dadas pelos deputados no ato da votação transformaram uma atividade de caráter parlamentar em um grande show midiático. 
Tabela 1

Frequências das Justificativas dos Deputados ao Votar

\begin{tabular}{|c|c|c|c|c|}
\hline $\begin{array}{l}\text { Ordem das } \\
\text { frequências }\end{array}$ & $\begin{array}{l}\text { Justificativa } \\
\text { (item) }\end{array}$ & $\begin{array}{l}\text { Indicadores } \\
\text { (termos e expressóes citados) }\end{array}$ & $\begin{array}{l}\text { Número de } \\
\text { deputados }\end{array}$ & $\%$ \\
\hline 1 & Pela base eleitoral do deputado & $\begin{array}{l}\text { Por minha cidade, meu estado, minha regiáo, pelo povo de } \\
\text { minha cidade (também cada local com o nome declarado) }\end{array}$ & 321 & 62,8 \\
\hline 2 & Pelo Brasil & Pelo Brasil, pelo país, pela pátria & 195 & 38,2 \\
\hline 3 & Pela família e parentes do deputado & $\begin{array}{l}\text { Por minha família, por meu pai, minha mãe, meu(s) irmão(s), } \\
\text { meu(s) filho(s) e filha(s), meu(s) neto(s) }\end{array}$ & 136 & 26,6 \\
\hline 4 & Pela democracia & Pela democracia, pelo Estado democrático & 91 & 17,8 \\
\hline 5 & Em nome do povo brasileiro & $\begin{array}{l}\text { Pelo povo, pelo povo brasileiro, em nome do nosso povo, por } \\
\text { todos os brasileiros }\end{array}$ & 81 & 15,9 \\
\hline 6 & Pela esperança e pelas novas geraçóes & Pelo futuro do país, em nome das novas gerações & 70 & 13,7 \\
\hline 7 & $\begin{array}{l}\text { Pela legalidade, votos em Dilma, } \\
\text { contra o golpe }\end{array}$ & $\begin{array}{l}\text { Pela legalidade, pelos milhóes de votos que elegeram a } \\
\text { presidente, contra o golpe }\end{array}$ & 67 & 13,1 \\
\hline 8 & Contra a corrupçâo e ladroagem & $\begin{array}{l}\text { Contra a corrupçáo e os corruptos, contra a ladroagem, os } \\
\text { ladrốes do patrimônio nacional, contra os bandidos }\end{array}$ & 66 & 12,9 \\
\hline 9 & Pela Constituição & Pela Constituição, pela Carta Magna & 65 & 12,7 \\
\hline 10 & Em nome do partido do deputado & Por meu partido & 53 & 10,4 \\
\hline 11 & Em nome de Deus & Em nome de Deus, por Deus, sob a proteçáa de Deus & 46 & 9,0 \\
\hline 12 & $\begin{array}{l}\text { Pela instituição da família, pela } \\
\text { família brasileira }\end{array}$ & $\begin{array}{l}\text { Pela família, pela família que o PT quis destruir, pela família } \\
\text { brasileira }\end{array}$ & 36 & 7,0 \\
\hline 12 & $\begin{array}{l}\text { Em nome de personagens históricos } \\
\text { e políticos }\end{array}$ & $\begin{array}{l}\text { Em nome de Ulysses Guimarães, por Teotônio Vilela, pela } \\
\text { memória de Marighela, por Zumbi dos Palmares, entre outros }\end{array}$ & 36 & 7,0 \\
\hline 14 & Pelos marginalizados sociais & Pelos pobres, pelos movimentos sociais, pelos desempregados & 35 & 6,8 \\
\hline 15 & Pela ética no governo, pela Lava Jato & $\begin{array}{l}\text { Pela operação Lava Jato, pelo juiz Moro, pela ética no } \\
\text { governo, por um governo ético, pela república de Curitiba. }\end{array}$ & 34 & 6,7 \\
\hline 16 & Contra o mau governo da presidente & $\begin{array}{l}\text { Contra as pedaladas fiscais, a política de recessão, a inflação, } \\
\text { as falências de empresas, a crise econômica; contra a } \\
\text { incompetência, improbidade administrativa, o rombo nos } \\
\text { cofres, o crime de responsabilidade fiscal, o mau governo }\end{array}$ & 33 & 6,5 \\
\hline 16 & Pelos trabalhadores do Brasil & Em nome dos trabalhadores, pelos empregados & 33 & 6,5 \\
\hline 18 & Contra Lula e contra o PT & $\begin{array}{l}\text { Pelo fim do governo do PT, contra a continuação de Lula e } \\
\text { sua corja, fora Lula, fora PT }\end{array}$ & 31 & 6,1 \\
\hline 19 & $\begin{array}{l}\text { Pela categoria profissional do } \\
\text { deputado }\end{array}$ & $\begin{array}{l}\text { Pelos advogados, corretores de imóveis, médicos, entre outras } \\
\text { categorias profissionais citadas }\end{array}$ & 23 & 4,5 \\
\hline 19 & Pela voz das ruas & $\begin{array}{l}\text { Pela voz das ruas, pelos que foram à rua para protestar, pelas } \\
\text { manifestaçóes de rua, pelo MBL, pelos "Revoltados Online" }\end{array}$ & 23 & 4,5 \\
\hline 21 & Pela retomada do desenvolvimento & $\begin{array}{l}\text { Pela retomada do crescimento econômico, pelo } \\
\text { desenvolvimento, pela retomada da economia }\end{array}$ & 21 & 4,1 \\
\hline 22 & $\begin{array}{l}\text { Pelo bom governo do PT e da } \\
\text { presidente }\end{array}$ & $\begin{array}{l}\text { Pelas políticas públicas, pelo aumento efetivo de postos de } \\
\text { trabalho, pela Minha Casa Minha Vida, bolsa família, Fies }\end{array}$ & 15 & 2,9 \\
\hline 23 & $\begin{array}{l}\text { Pela igreja e fieis da religiáo do } \\
\text { deputado }\end{array}$ & $\begin{array}{l}\text { Em nome da minha igreja (denominação específica), pelos } \\
\text { evangélicos, pelos carismáticos, pelo povo de Israel, pelos } \\
\text { neopentecostais, pelos carismáticos }\end{array}$ & 14 & 2,7 \\
\hline 23 & Pela liberdade e justiça & Pela justiça, pela liberdade & 14 & 2,7 \\
\hline 25 & Porque não há golpe & $\begin{array}{l}\text { Com a consciência de que não está havendo nenhum golpe, } \\
\text { porque não há golpe }\end{array}$ & 9 & 1,8 \\
\hline 26 & Pelos que sofreram com a ditadura & Em nome dos que sofreram pela ditadura, os torturados & 7 & 1,4 \\
\hline
\end{tabular}

Total de deputados votantes $=511$.

Fonte: Dados elaborados pelos autores com base na transcrição da sessão de votação da admissibilidade do impeachment de Dilma Rousseff pelos deputados federais, disponibilizada pelo Departamento de Taquigrafia, Revisão e Redação da Câmara dos Deputados. 
Conforme mostra a Tabela 1 , a base eleitoral foi citada por 321 deputados ou $62,8 \%$ deles, isto é, por mais da metade da Câmara. Foi de longe a justificativa mais frequente. $\mathrm{O}$ deputado fez questão de se referir a seus representados ao votar nessa sessão, que poderá por muito tempo ser lembrada.

Em segundo lugar, o deputado votou, a favor ou contra, ou se absteve em nome do Brasil, resposta tanto vaga quanto esperada. Foram 195 deputados, perfazendo $38,2 \%$ dos eleitores, pouco mais que a metade das citações da base eleitoral. Claro que as duas justificativas, e todas as possíveis combinaçóes delas com as demais, podem ter sido mencionadas juntas.

O terceiro posto coube à família do deputado, que pode ter nomeado a família como um todo ou diferentes membros, da mãe já falecida ao neto recém-nascido. Foram 136 casos, ou 26,6\% dos 511 votantes.

A democracia ocupou o quarto lugar, citada por $17,8 \%$ dos deputados. Na ordem se apresentaram: "o meu lugar”, "o meu país”, "a minha família", "a democracia”.

O item "pela esperança e pelo futuro das novas geraçóes", em sexto lugar, obteve uma taxa de $13,7 \%$. Considerando que as justificativas necessariamente nâo se excluem umas às outras, um mesmo deputado poderia, por exemplo, ter citado todas as que aqui já foram apresentadas. Adiante veremos, contudo, que os itens podem ser reunidos em grupos específicos por seus próprios significados.

A afirmação da legalidade, que incluiu os milhóes de votos dados à presidente Dilma em sua eleição, a ideia de que o impeachment da presidente se tratava de um golpe, portanto ilegal, foi citada por $13,1 \%$ dos deputados. Logo depois, com 12,9\% está o item corrupção e ladroagem. A Constituição, por sua vez, justificou $12,7 \%$ dos votos. E o partido a que pertence o deputado, $10,4 \%$, citado tanto como referência identitária e objeto de homenagem como fonte determinante do voto do deputado que, ao votar, diz simplesmente que está seguindo a decisão de seu partido. Às vezes o deputado encaminha seu voto como quem vai votar "não", e no final justifica que seu partido tem posição diferente da sua e em respeito à sua filiação partidária ele vota "sim".

Depois desses, Deus aparece no décimo primeiro lugar, com apenas 9,0\% de citaçóes. Lugar mo- desto, se considerarmos as muitas críticas à Câmara, e até as piadas e pilhérias, que o voto "em nome do Pai" mereceu na impressa. Igualmente modesto se consideramos que os deputados que se identificam como religiosos, e que se propóem a votar como tal, representaram cerca de $16 \%$ dos votantes. Por aí já se nota que a orientação religiosa, mesmo no plano simbólico das justificativas de voto, teve bem menos peso nesse processo político do que querem fazer parecer aqueles "eternos descontentes com a autonomização das esferas de valor e a separação de competências" (Pierucci, 2008b, p. 11).

Por ordem decrescente de classificação, seguem-se a família como instituição $(7,0 \%)$, as justificativas que remeteram a personagens históricos e políticos $(7,0 \%)$, a citação dos marginalizados sociais $(6,8 \%)$ e os motivos que clamam à ética na política, à operação Lava Jato e seu juiz Sérgio Moro (6,7\%).

As chamadas pedaladas fiscais, por sua vez, foram relativamente pouco citadas. Reunidas com as referências às consequências econômicas e sociais de um avaliado mau governo, somaram apenas 6,5\%. Quase nada, quando a acusaçáo de crime de responsabilidade foi o motivo legal para a abertura do processo contra a presidente.

$\mathrm{O}$ voto em nome dos trabalhadores do Brasil representou $6,5 \%$, quase igual aos $6,1 \%$ de referências contra Lula e Dilma, desenhando-se um belo par de contrários.

Houve quem votasse em nome de sua categoria profissional na vida fora do parlamento $(4,5 \%)$. Porcentagem igual mereceram a voz das ruas e os movimentos a favor e contra o impeachment, enquanto $4,1 \%$ justificaram seu voto em nome da necessidade de retomada do desenvolvimento econômico. O que mais se citou depois disso foi o bom governo da presidente e do PT (2,9\%).

Entre as justificativas menos citadas estiveram as igrejas, movimentos e denominaçóes religiosas a que os deputados pertencem $(2,7 \%)$, os lemas de liberdade e justiça $(2,7 \%)$, e a afirmação de que assim se vota porque não há golpe no processo de afastamento da presidente Rousseff (1,8\%). A justificativa de que assim se votou pelos que sofreram com a ditadura militar, em último lugar nesta contagem, obteve $1,4 \%$. 
Viu-se que os alegados motivos do voto citados foram muito diferentes entre si, embora cada um raramente tenha aparecido isoladamente, mas fazendo parte de um elenco de razóes para afastar a presidente ou não. Algumas tratam de economia, outras da identidade do parlamentar, outras mais de fatos e categorias sociais relevantes para o deputado e assim por diante. Buscando reduzir essa dispersão e tornar os dados mais claros, os 26 itens de justificativas foram submetidos a uma análise fatorial para identificar as possíveis diferentes dimensóes a que cada item poderia estar associado.

Considerando cada grupo de justificativa como uma variável dummy, que assume o valor um quando há citação daquele item e zero quando não há, os dados foram submetidos a um modelo fatorial que parte das intercorrelaçóes entre cada par de variáveis e se pergunta como as variáveis poderiam ser agrupadas em dimensóes independentes, que são, evidentemente, construçóes abstratas (McDonald, 1985). O modelo questiona se as variáveis poderiam ser separadas em grupos, de modo que cada grupo se remeta a um aspecto específico da realidade abstrata descrita pelo conjunto empírico dos itens que alimentam o modelo.

Os resultados principais da análise fatorial estão mostrados na Tabela 2, identificando cinco eixos principias (componentes, fatores ou dimensóes) aos quais cada uma das variáveis está associada em maior ou menor grau. Tal associação é medida pela carga fatorial, espécie de coeficiente de correlação da variável com o fator. Esse coeficiente pode variar de um a zero, e quanto maior seu valor, maior a associação do item com a dimensão em questão. Considerando os itens mais fortemente correlacionados com cada fator e tendo como base a análise qualitativa dos conteúdos dos itens (justificativas), foi possível identificar e nomear os diferentes aspectos a que cada fator se refere. Esse tipo de análise requer uma interpretação qualitativa, que busque entender o que cada fator significa, a que dimensões da realidade em questão se refere. As variáveis com cargas fatoriais pequenas são excluídas do modelo, uma vez que pouco contribuem para melhorar a representatividade estatística dos fatores. Em outras palavras, o fator pode ser representado pelas variáveis de carga fatorial elevada, mas não por aquelas que apresentaram carga de menor magnitude. Adotou-se 0,20 como valor mínimo de inclusão. Em suma, esse tipo de construção permite partir de um conjunto grande de variáveis, identificar a que dimensóes elas estão associadas e, a partir daí, selecionar as mais representativas.

A partir dos resultados encontrados, as justificativas ao voto pela admissibilidade do impeachment foram reunidas em cinco dimensões que tratam, cada uma, dos seguintes temas: 1) democracia; 2) bom governo e programas sociais; 3 ) mau governo e corrupção; 4) legalidade; 5) tradição. Esses nomes foram atribuídos a partir das variáveis que cada fator agrega.

Alinham-se no eixo da democracia os itens "legalidade", "democracia", "trabalhadores" e "os que sofreram sob a ditadura".

Compóe a dimensão bom governo e programas sociais os itens "bom governo", "marginalizados sociais", "retomada do desenvolvimento".

O mau governo e a corrupção, por sua vez, está associado mais fortemente aos itens "contra Lula e o PT", o "mau governo da presidente", a "voz das ruas" e a "corrupção". O quarto fator, que se denominou legalidade, inclui os itens "pela liberdade e justiça”, "pela Constituição" e "pelo povo brasileiro".

A quinta dimensão reúne igreja, Deus, a instituição da família, a família do deputado, a base eleitoral do deputado e o país. Não podia deixar de ser chamada de tradiçấo. O item "porque não há golpe" também foi incluído nessa dimensão pelo modelo de análise fatorial empregado. Embora pudesse significar não ruptura ou continuidade da normalidade, que são condiçóes que qualificam a tradição, optou-se, qualitativamente, por sua exclusão, uma vez que a interpretação de sua inclusão como indicador da dimensão tradição é menos direta do que a dos demais itens. Por "tradição", não é demais relembrar, entendem-se diferentes elementos remanescentes do conjunto não questionável, real ou pressuposto, de valores morais e espirituais, crenças e normas de conduta, mitos e ritos, técnicas e processos sociais legados pelo passado e transmitidos de geração a geração, os quais em épocas passadas integravam um modelo que articulava a vida social como um 
Tabela 2

Resultado da Análise Fatorial para Extraçáo dos Componentes Principais (Cargas Fatoriais)

\begin{tabular}{|c|c|c|c|c|c|}
\hline \multirow[t]{2}{*}{ Justificativa (item) } & \multicolumn{5}{|c|}{ Dimensóes (componentes principais) } \\
\hline & $\begin{array}{l}\text { 1: } \\
\text { democracia }\end{array}$ & $\begin{array}{l}2: \\
\text { bom governo e } \\
\text { programas sociais }\end{array}$ & $\begin{array}{l}\text { 3: } \\
\text { mau governo } \\
\text { e corrupçáo }\end{array}$ & $\begin{array}{l}\text { 4: } \\
\text { legalidade }\end{array}$ & $\begin{array}{l}\text { 5: } \\
\text { tradição }\end{array}$ \\
\hline \multicolumn{6}{|l|}{ Pela legalidade, votos, golpe } \\
\hline \multicolumn{6}{|l|}{ Pela democracia } \\
\hline \multicolumn{6}{|l|}{ Pelos trabalhadores do Brasil } \\
\hline \multicolumn{6}{|l|}{ Pelos que sofreram com a ditadura } \\
\hline $\begin{array}{l}\text { Pelo bom governo do PT e da } \\
\text { presidente }\end{array}$ & & 0,816 & & & \\
\hline Pelos marginalizados sociais & & 0,577 & & & \\
\hline Pela retomada do desenvolvimento & & 0,213 & & & \\
\hline Contra Lula e contra o PT & & & 0,851 & & \\
\hline Contra o mau governo da presidente & & & 0,452 & & \\
\hline Pela voz das ruas & & & 0,306 & & \\
\hline Contra a corrupçáo e ladroagem & & & 0,233 & & \\
\hline Pela liberdade e justiça & & & & 0,674 & \\
\hline Pela Constituição & & & & 0,480 & \\
\hline Em nome do povo brasileiro & & & & 0,473 & \\
\hline $\begin{array}{l}\text { Pela igreja e fieis da religião do } \\
\text { deputado }\end{array}$ & & & & & 0,852 \\
\hline Em nome de Deus & & & & & 0,559 \\
\hline $\begin{array}{l}\text { Pela instituição da família, } \\
\text { pela família brasileira }\end{array}$ & & & & & 0,466 \\
\hline Pela família e parentes do deputado & & & & & 0,402 \\
\hline Porque não há golpe & & & & & 0,284 \\
\hline Pela base eleitoral do deputado & & & & & 0,269 \\
\hline Pelo Brasil & & & & & 0,206 \\
\hline
\end{tabular}

Notas:

1 Variáveis excluídas (carga fatorial menor que 0,20): "pela esperança e pelas novas geraçóes"; "em nome do partido do deputado"; "em nome de personagens históricos e políticos"; "pela ética no governo"; "pela Lava Jato"; "pela categoria profissional do deputado".

2 Análise fatorial com extração de componentes principais, rotação Varimax, exclusão com carga menor que 0,2.

3 Para melhor visualização estáo apresentadas na tabela, em ordem decrescente, somente as cargas fatoriais das variáveis mais relacionadas com o fator.

Fonte: Dados elaborados pelos autores com base na transcrição da sessão de votação da admissibilidade do impeachment de Dilma Rousseff pelos deputados federais, disponibilizada pelo Departamento de Taquigrafia, Revisáo e Redação da Câmara dos Deputados. 
todo. Elementos da tradição ainda presentes na vida moderna, com maior ou menor importância, continuam associados à ideia de estabilidade social e não mudança, cultivados com especial ênfase pela religião (Prandi, 2008; Weber, 1991).

O resultado da análise fatorial, portanto, permite reduzir os 26 itens a cinco variáveis por meio de construção de escalas. Para manter a referência mais direta ao que de fato foi dito, preferiu-se, contudo, trabalhar com os itens originais, apresentando-os reunidos no grupo e na ordem indicados pela análise fatorial. Cinco itens foram excluídos por não se encaixarem estatisticamente nos cinco fatores considerados: "pelas novas geraçóes", o partido do deputado, os personagens históricos e políticos, a ética na política e a categoria profissional do deputado. O item "porque não há golpe" foi excluído por sua difícil interpretação.

Vale a pena esclarecer que o fato de a dimensão democracia representar o fator 1 e a tradição o fator 5 significa apenas que os itens que se juntam em democracia estão mais fortemente correlacionados entre si do que com os demais itens, além de serem mais facilmente destacados; poderia se dizer que sáo separados em uma primeira peneirada. Em oposição, os itens que se juntam para representar a dimensão tradição têm uma maior dispersão no conjunto. Isso se aplica também aos outros três fatores. Também deve ser lembrado que o voto a favor ou contra, ou a abstenção não foi levada em conta na identificação dos fatores, assim como a pertença à Bancada Evangélica e demais variáveis.

\section{Justificativa dos votos a favor e contra}

A Tabela 3 mostra como o voto do deputado está associado ao discurso que o justifica. Voto "sim" e voto "náo" estão, cada um, afeitos a dimensóes bem diferentes do mundo que o discurso dos seus votantes constrói.

Os que se referiram à dimensão democracia tenderam fortemente a votar "não", isto é, contra a admissibilidade do impeachment da presidente. Já os que votaram a favor do não recorreram frequentemente à dimensão democracia. Os itens dessa dimensão que melhor separaram os votos "não" dos votos "sim" foram: 1) a menção à democracia, simplesmente, com porcentagem de 56,2\% associada ao voto não e de 3,8\% ao voto sim; 2) seguida da justificativa que junta a citação da legalidade, os milhóes de votos que elegeram Dilma e de que estava havendo um golpe, com taxas de $44,5 \%$ no caso de voto contra o processo de impeachment e de $3,8 \%$ quando o voto foi a favor.

$\mathrm{Na}$ dimensão bom governo, houve maior associação com o voto "não" quando foram lembrados pelo votante os grupos sociais marginalizados (16,8\% dos que votaram "náo" contra $3,0 \%$ dos que votaram "sim") e com uma avaliação positiva do governo da presidente e seu partido (2,9\% para $0,3 \%$, respectivamente). Mas ao fazer referência a uma retomada do desenvolvimento, o deputado tendeu a votar "sim" (2,9\% contra $0,3 \%)$.

A clara associação entre voto e justificativa volta a ocorrer nos fatores seguintes. Quem se justificou citando o mau governo e a corrupção, votou em geral a favor do impeachment, e todos os itens dessa dimensão mostraram diferenças expressivas associadas ao voto "sim". A maior taxa foi observada para o item contra a corrupçáo e a ladroagem, com 16,1\% no grupo de quem votou "sim" e 3,6\% entre quem votou não. Quem falou em legalidade, votou contra a abertura do processo, obtendo o item "pela Constituição" o maior contraste $(24,1 \%$ com voto "não" e $8,4 \%$ com voto "sim").

Os que sustentaram seu voto na tradição, o que é mais interessante aqui, votaram preferencialmente contra Dilma: "pelo meu lugar" $(77,1 \%$ com voto "sim" versus $24,8 \%$ com voto "não"), "pelo meu país" (46,3\% no grupo "sim" e 17,5\% no grupo "não"), "minha família" $(35,1 \%$ e $4,4 \%$, respectivamente), "por Deus" (35,1\% e 4,4\%), "pela família brasileira" (8,7\% e $2,9 \%)$, "por minha igreja e meus companheiros de fé" (3,8\% e zero), "porque não há golpe" (2,5\% e zero).

Em suma, os que votaram pela admissibilidade do impeachment citaram preferencialmente justificativas que compóem a dimensão mau governo e corrup̧̧ão e as que fazem parte da dimensão tradição. Os deputados que votaram a favor de Dilma e contra a admissibilidade do impeachment apoiaram seus votos nas dimensóes democracia e legalidade. Convém ressaltar que palavra "República" foi citada apenas quatro 
Tabela 3

Porcentagens das Justificativas Segundo o Voto

\begin{tabular}{|c|c|c|c|c|}
\hline Dimensão da justificativa & Item & Sim & Não & Total* \\
\hline \multirow[t]{4}{*}{ Democracia } & Pela democracia & 3,8 & 56,2 & 17,8 \\
\hline & Pela legalidade, votos em Dilma, contra o golpe & 1,6 & 44,5 & 13,1 \\
\hline & Pelos trabalhadores do Brasil & 2,2 & 18,2 & 6,5 \\
\hline & Pelos que sofreram com a ditadura & 0,3 & 4,4 & 1,4 \\
\hline \multirow{3}{*}{$\begin{array}{l}\text { Bom governo e programas } \\
\text { sociais }\end{array}$} & Pelos marginalizados sociais & 3,0 & 16,8 & 6,8 \\
\hline & Pela retomada do desenvolvimento & 4,9 & 2,2 & 4,1 \\
\hline & Pelo bom governo do PT e da presidente & 0,3 & 2,9 & 2,9 \\
\hline \multirow[t]{4}{*}{ Mau governo e corrupçáo } & Contra a corrupção e ladroagem & 16,1 & 3,6 & 12,9 \\
\hline & Contra o mau governo da presidente & 8,7 & 0,7 & 6,5 \\
\hline & Contra Lula e contra o PT & 8,4 & 0,0 & 6,1 \\
\hline & Pela voz das ruas & 4,6 & 4,4 & 4,5 \\
\hline \multirow[t]{3}{*}{ Legalidade } & Em nome do povo brasileiro & 15,5 & 17,5 & 15,9 \\
\hline & Pela Constituição & 8,4 & 24,1 & 12,7 \\
\hline & Pela liberdade e justiça & 2,2 & 4,4 & 2,7 \\
\hline \multirow[t]{6}{*}{ Tradição } & Pela base eleitoral do deputado & 77,1 & 24,8 & 62,8 \\
\hline & Pelo Brasil & 46,3 & 17,5 & 38,2 \\
\hline & Pela família e parentes do deputado & 35,1 & 4,4 & 26,6 \\
\hline & Em nome de Deus & 11,4 & 2,9 & 9,0 \\
\hline & $\begin{array}{l}\text { Pela instituição da família, pela família } \\
\text { brasileira }\end{array}$ & 8,7 & 2,9 & 7,0 \\
\hline & Pela igreja e fieis da religiáo do deputado & 3,8 & 0,0 & 2,7 \\
\hline Número de deputados & & 367 & 137 & $511^{*}$ \\
\hline
\end{tabular}

* Inclui sete casos de abstenção. Dos 513 deputados, dois estiveram ausentes.

Fonte: Dados elaborados pelos autores com base na transcrição da sessão de votação da admissibilidade do impeachment de Dilma Rousseff pelos deputados federais, disponibilizada pelo Departamento de Taquigrafia, Revisão e Redação da Câmara dos Deputados.

vezes no conjunto de todos os votos e, por isso, sequer entrou na lista de indicadores dos itens.

O discurso dos deputados, proferido imediatamente antes do voto, foi seguido de um ato político de consequências notáveis. Não se tratou do discurso pelo discurso, da simples afirmação de identidade política e mesmo de bravata parlamentar, mas do envoltório ideológico, ainda que simples e nem sempre decisivo e verdadeiro, de uma ação capaz de alterar os rumos do governo, com todas as reorientaçóes que isso pode acarretar em termos sociais, econômicos e, evidentemente, políticos, com efeitos de âmbito nacional e internacional.

\section{Como a Bancada Evangélica votou e justificou o voto}

Depois dessa visão geral que reúne todos os deputados, cabe averiguar agora se os deputados que compóem a Bancada Evangélica se mostram diferentes dos demais quando se trata de justificar 
o voto. Em outras palavras, qual seria o efeito da religião (no caso desses militantes parlamentares, todos eles cristãos evangélicos) no discurso que reveste sua atuação política?

Os dados para responder a essa questão esta na Tabela 4. Tratou-se inicialmente de verificar se as justificativas dos deputados da Bancada Evangélica divergem daquelas dadas pelos que não participam dessa bancada, independentemente do voto a favor ou contra a admissibilidade do impeachment. Depois, de comparar as justificativas de todos os deputados, independentemente do voto dado, com as justificativas daqueles que votaram a favor da admissibilidade, comparando-se a seguir esses resultados com os observados para os membros da Bancada Evangélica que votaram a favor da admissibilidade. $\mathrm{O}$ pequeno número de deputados da Bancada que votou a favor de Dilma (cinco casos) não permite cruzar as variáveis, mas o efeito dela pode ser observado quando se compara o conjunto de todos os deputados com os que votaram sim independentemente de ser ou não evangélico e com os que votaram "sim" e "não" da Bancada.

Inicialmente, pode-se ver que em todos os itens da dimensão democracia as citaçóes dos evangélicos foram muito menos frequentes do que as observadas no conjunto dos deputados que não participam da Bancada Evangélica $(5,0 \%$ a 20,2\%; 12,5\% a $15,1 \%$; zero a $7,7 \%$; zero a $1,6 \%$; segundo a ordem dos itens na Tabela 4). Na dimensão bom governo os evangélicos ficam à frente somente quando a justificativa inclui os marginalizados sociais $(8,8 \%$ a 6,5\%). Em geral, os evangélicos citam mais que os não evangélicos os itens que formam a dimensão mau governo. Na dimensão legalidade apenas a citação do povo brasileiro é mais presente entre os evangélicos, que citam menos os demais itens. $\mathrm{Na}$ dimensão tradição os evangélicos atingem taxas maiores que os demais deputados em todos os itens. Eles se distinguem sobretudo quando se trata dos itens Deus, família e igreja. A citação de Deus apresenta a maior diferença, como era de se esperar, e está presente em 32,5\% no grupo evangélico contra 4,6\% entre os não evangélicos.

Observando-se agora as três últimas colunas da tabela, ou seja, passando-se do conjunto de todos os deputados que votaram naquele dia para o grupo dos deputados que votaram pelo impeachment e de- pois para aquele formado pelos representantes membros da Bancada Evangélica que votaram "sim", têm-se resultados que confirmam o efeito da religião no discurso (como aconteceu no próprio voto), indicando justificativas menos democráticas e mais tradicionais quando o voto é pelo impeachment e quando o deputado é de religiấo evangélica.

Nas dimensōes bom governo, mau governo e legalidade, há flutuaçóes em alguns itens (sobretudo quando se trata de mençóes ao povo e aos marginalizados, que merecem atenção especial da religião, como só podia ser), já apontadas anteriormente, mas em democracia todos os itens mostram tendência decrescente nas citaçóes ao passarem de (1) todos os deputados para (2) os que votaram "sim" e destes para (3) os que votaram "sim" e são membros da Bancada Evangélica. Nessa ordem, as porcentagens são:

- Pela democracia: $17,8 \%>3,8 \%>2,7 \%$.

- Pela legalidade, votos em Dilma, contra o golpe: $13,1 \%>1,6 \%>1,3 \%$.

- Pelos trabalhadores do Brasil: $6,5 \%>2,2 \%>$ $0,0 \%$.

- Pelos que sofreram com a ditadura: $1,4 \%>$ $0,3 \%>0,0 \%$.

Tudo se inverte quando se trata da dimensão tradiçâo: em cada item, a porcentagem de citação sobe ao passarmos de (1) todos os deputados que votaram para (2) os que votaram "sim" e destes para (3) os que votaram "sim" e são membros da Bancada Evangélica. As porcentagens, num crescendo constante, são as seguintes:

- Pela base eleitoral do deputado: $62,8 \%$ < $77,1 \%<74,7 \%$.

- $\quad$ Pelo Brasil: $38,2 \%<46,3 \%<40,0 \%$.

- Pela família e parentes do deputado: $26,6 \%<$ $35,1 \%<33,3 \%$.

- Em nome de Deus: 9,0\% < 11,4\% <33,0\%.

- Pela instituição da família, pela família brasileira: $7,0 \%<8,7 \%<4,7 \%$.

- Pela igreja e fieis da religião do deputado: $2,7 \%$ $<3,8 \%<16,0 \%$.

Claro que não foi somente a religião em si que alinhou a Bancada Evangélica contra Dilma e re- 
Tabela 4

Justificativas Segundo Participaçáo na Bancada Evangélica e Voto

\begin{tabular}{|c|c|c|c|c|c|c|}
\hline $\begin{array}{l}\text { Dimensão da } \\
\text { justificativa }\end{array}$ & Item & $\begin{array}{l}\text { Todos os } \\
\text { deputados } \\
\text { da Bancada } \\
\text { Evangélica }\end{array}$ & $\begin{array}{l}\text { Todos os } \\
\text { deputados } \\
\text { nâo membros } \\
\text { da Bancada } \\
\text { Evangélica }\end{array}$ & $\begin{array}{l}\text { Todos os deputados } \\
\text { independentemente do } \\
\text { voto dado }\end{array}$ & $\begin{array}{l}\text { Todos os } \\
\text { deputados que } \\
\text { votaram sim }\end{array}$ & $\begin{array}{l}\text { Deputados } \\
\text { da Bancada } \\
\text { Evangélica que } \\
\text { votaram sim }\end{array}$ \\
\hline \multirow[t]{4}{*}{ Democracia } & Pela democracia & 5,0 & 20,2 & 17,8 & 3,8 & 2,7 \\
\hline & $\begin{array}{l}\text { Pela legalidade, votos } \\
\text { em Dilma, contra o } \\
\text { golpe }\end{array}$ & 2,5 & 15,1 & 13,1 & 1,6 & 1,3 \\
\hline & $\begin{array}{l}\text { Pelos trabalhadores } \\
\text { do Brasil }\end{array}$ & 0,0 & 7,7 & 6,5 & 2,2 & 0,0 \\
\hline & $\begin{array}{l}\text { Pelos que sofreram } \\
\text { com a ditadura }\end{array}$ & 0,0 & 1,6 & 1,4 & 0,3 & 0,0 \\
\hline \multirow[t]{3}{*}{$\begin{array}{l}\text { Bom governo e } \\
\text { programas sociais }\end{array}$} & $\begin{array}{l}\text { Pelos marginalizados } \\
\text { sociais }\end{array}$ & 8,8 & 6,5 & 6,8 & 3,0 & 8,0 \\
\hline & $\begin{array}{l}\text { Pela retomada do } \\
\text { desenvolvimento }\end{array}$ & 3,8 & 4,2 & 4,1 & 4,9 & 2,7 \\
\hline & $\begin{array}{l}\text { Pelo bom governo do } \\
\text { PT e da presidente }\end{array}$ & 0,0 & 1,4 & 2,9 & 0,3 & 0,0 \\
\hline \multirow[t]{4}{*}{$\begin{array}{l}\text { Mau governo e } \\
\text { corrupção }\end{array}$} & $\begin{array}{l}\text { Contra a corrupçáo e } \\
\text { ladroagem }\end{array}$ & 21,3 & 11,4 & 12,9 & 16,1 & 22,7 \\
\hline & $\begin{array}{l}\text { Contra o mau } \\
\text { governo da presidente }\end{array}$ & 5,0 & 6,7 & 6,5 & 8,7 & 5,3 \\
\hline & $\begin{array}{l}\text { Contra Lula e contra } \\
\text { o PT }\end{array}$ & 18,8 & 3,7 & 6,1 & 8,4 & 20,0 \\
\hline & Pela voz das ruas & 5,0 & 4,4 & 4,5 & 4,6 & 5,3 \\
\hline \multirow[t]{3}{*}{ Legalidade } & $\begin{array}{l}\text { Em nome do povo } \\
\text { brasileiro }\end{array}$ & 27,5 & 13,7 & 15,9 & 15,5 & 28,0 \\
\hline & Pela Constituiçãoo & 7,5 & 13,7 & 12,7 & 8,4 & 6,7 \\
\hline & $\begin{array}{l}\text { Pela liberdade e } \\
\text { justiça }\end{array}$ & 1,3 & 3,0 & 2,7 & 2,2 & 0,0 \\
\hline \multirow[t]{6}{*}{ Tradiç̧ão } & $\begin{array}{l}\text { Pela base eleitoral do } \\
\text { deputado }\end{array}$ & 73,8 & 60,8 & 62,8 & 77,1 & 74,7 \\
\hline & Pelo Brasil & 38,8 & 38,1 & 38,2 & 46,3 & 40,0 \\
\hline & $\begin{array}{l}\text { Pela família e } \\
\text { parentes do deputado }\end{array}$ & 31,3 & 25,8 & 26,6 & 35,1 & 33,3 \\
\hline & Em nome de Deus & 32,5 & 4,6 & 9,0 & 11,4 & 33,0 \\
\hline & $\begin{array}{l}\text { Pela instituição da } \\
\text { família, pela família } \\
\text { brasileira }\end{array}$ & 13,8 & 5,8 & 7,0 & 8,7 & 14,7 \\
\hline & $\begin{array}{l}\text { Pela igreja e fieis da } \\
\text { religiấo do deputado }\end{array}$ & 15,0 & 0,5 & 2,7 & 3,8 & 16,0 \\
\hline \multicolumn{2}{|c|}{ Número de deputados } & 80 & 431 & $511^{*}$ & 367 & 75 \\
\hline
\end{tabular}

* Do total de 513 deputados, dois não compareceram.

Fonte: Dados elaborados pelos autores com base na transcrição da sessão de votação da admissibilidade do impeachment de Dilma Rousseff pelos deputados federais, disponibilizada pelo Departamento de Taquigrafia, Revisão e Redação da Câmara dos Deputados. 
Tabela 5

Médias Ponderadas Obtidas para as Dimensóes Segundo Voto e Bancada Evangélica*

\begin{tabular}{|c|c|c|c|c|c|c|}
\hline \multirow[t]{2}{*}{ Grupos } & & \multicolumn{5}{|c|}{ Dimensôes (fatores) } \\
\hline & & Democracia & $\begin{array}{l}\text { Bom } \\
\text { governo e } \\
\text { programa } \\
\text { sociais }\end{array}$ & $\begin{array}{l}\text { Mau } \\
\text { governo e } \\
\text { corrupção }\end{array}$ & Legalidade & Tradição \\
\hline \multirow{3}{*}{$\begin{array}{l}\text { Admissibilidade do } \\
\text { impeachment }\end{array}$} & a) voto $\operatorname{sim}$ & 0,03 & 0,02 & 0,09 & 0,08 & 0,19 \\
\hline & b) voto não & 0,35 & 0,08 & 0,01 & 0,14 & 0,05 \\
\hline & índice $100 \mathrm{a} /(\mathrm{a}+\mathrm{b})$ & $8 \%$ & $25 \%$ & $90 \%$ & $33 \%$ & $79 \%$ \\
\hline \multirow{3}{*}{ Bancada Evangélica } & a) pertence & 0,02 & 0,04 & 0,13 & 0,11 & 0,26 \\
\hline & b) não pertence & 0,12 & 0,04 & 0,07 & 0,09 & 0,11 \\
\hline & índice $100 \mathrm{a} /(\mathrm{a}+\mathrm{b})$ & $14 \%$ & $50 \%$ & $65 \%$ & $55 \%$ & $70 \%$ \\
\hline
\end{tabular}

* Valores dummy assumidos: voto "sim" (a favor) = 1; voto "não" = 0; pertencimento à Bancada Evangélica = 1; não pertencimento $=2$. Para o valor ponderado dos fatores, cada item foi considerado um quando citado e zero quando náo citado.

Fonte: Dados elaborados pelos autores com base na transcrição da sessão de votação da admissibilidade do impeachment de Dilma Rousseff pelos deputados federais, disponibilizada pelo Departamento de Taquigrafia, Revisão e Redação da Câmara dos Deputados.

velou as justificativas apresentadas, que primaram por uma postura tradicional descolada de maiores critérios democráticos. Há sempre interesses próprios do grupo, legítimos ou escusos, que envolvem alianças, novos compromissos e mesmo traiçóes. Segundo Marcella Fernandes e Grasielle Castro:

Após declarar apoio ao impeachment da presidente Dilma Rousseff, a bancada tem se reunido com o vice-presidente, Michel Temer, em busca de apoio. [...] $\mathrm{Na}$ agenda pós-impeachment, as prioridades da Bancada Evangélica são: o Estatuto da Família (PL 6583/2013), o Estatuto do Nascituro (PL478/2007) e a PEC 99/2011, que permite [a] entidades religiosas propor ação direta de inconstitucionalidade e ação declaratória de constitucionalidade ao Supremo Tribunal Federal. Atualmente essa prerrogativa é restrita a chefes do Executivo e Legislativo federais e estaduais, ao procurador-geral da República, Conselho Federal da Ordem dos Advogados do Brasil $(\mathrm{OAB})$, partido político ou entidade de classe de âmbito nacional (Fernandes e Castro, 2016).
Faz sentido. Evangélicos seguem centrados preferencialmente em questóes que remetem à tradição. Não é de se estranhar, portanto, o número reduzido ou nulo de vezes em que membros da Bancada Evangélica que votaram "sim" e se referiram a temas como democracia, liberdade, justiça e, muito especialmente, desenvolvimento econômico, que não encontra lugar relevante em suas pautas no histórico de sua atuação parlamentar (Prandi e Santos, 2017).

Para resumir os dados, os itens considerados (que receberam o valor um no caso de ter sido citado e zero se não citado) foram ponderados pelas cargas fatoriais fornecidas pela análise fatorial, gerando uma variável síntese para cada uma das cinco dimensões consideradas. Os resultados estão na Tabela 5.

Considerando inicialmente o voto, as médias obtidas em cada dimensão mostram que democracia, bom governo e programas sociais e legalidade são marcas do voto a favor de Dilma, enquanto as médias para mau governo e corrupçáo e tradição estão mais ligadas ao voto "sim" pelo processo de afastamento. $\mathrm{O}$ índice calculado entre os pares de 
médias (voto "sim"/voto "não") alinha o voto "sim" primeiramente com mau governo (90\%), seguido de perto por tradição $(79 \%)$ e de longe por legalidade (33\%), bom governo (25\%) e democracia (8\%).

Analisando-se a pertença à Bancada Evangélica, as médias mais associadas aos membros da Bancada correspondem especialmente às dimensóes tradição, mau governo e legalidade, nessa ordem. A dimensão democracia se ajusta menos à Bancada Evangélica e mais ao grupo dos que dela não participam. O índice comparativo entre pertencer e não pertencer à Bancada Evangélica permite hierarquizar as dimensões em sua associação com ela: tradição (70\%), mau governo e corrupção (65\%), legalidade (55\%), bom governo $(50 \%)$ e, bem atrás, democracia (14\%).

Esses resultados sumariam e reiteram o que se apresentou anteriormente.

\section{Consideraçóes finais}

O eleitorado brasileiro é, em geral, mais conservador em temas da moralidade e dos comportamentos que seus representantes no Congresso Nacional, inclusive entre evangélicos (Prandi e Paulino, 2015; Prandi e Santos, 2017). A partir daí, a lógica partidária segue rumos em que os valores republicanos contam pouco, cedendo lugar a interesses e alianças partidárias, conchavos pessoais e promessas de postos e carreira, que podem usar a ideia de crime de responsabilidade como disparador de um processo em que provas e contraprovas têm pouco valor além do espetáculo do rito, incapaz de alterar decisóes previamente assumidas.

Ainda que a discussão sobre a existência ou não das pedaladas fiscais e sobre os méritos ou os equívocos que podem ter levado à aprovação da admissibilidade do processo de impeachment de Dilma Rousseff na Câmara dos Deputados tenha sua importância, não é esse o debate que está em jogo aqui. Para os propósitos deste artigo, o ponto a não perder de vista é que as justificativas oferecidas pelos deputados ao votar a favor ou contra a continuidade do processo de afastamento da presidente, em grande medida, deixaram para trás as razóes alegadas para a instauração do processo, que eram de ordem administrativa, e remeteram a ideais e valores de ordem moral, sobretudo a defesa da moral tradicional, que estaria em perigo com a continuidade do governo de Dilma Rousseff.

Para o conjunto da Câmara dos Deputados, os resultados mostraram que aqueles que votaram a favor da admissibilidade do impeachment, que foram a maioria, tenderam a justificar seu voto com base em diferentes aspectos que podem ser reunidos sob a rubrica da tradição, que inclui sentimentos referentes à família, à religião e à base eleitoral do deputado, somando-se a ela a avaliação de mau governo e corrupção. Os derrotados, que votaram contra o prosseguimento do processo de afastamento, calcaram seus votos preferencialmente em justificativas mais ligadas aos pressupostos da democracia e da legalidade do processo político.

$\mathrm{Na}$ tentativa de avançar uma explicação para tais diferenças, o trabalho se deteve sobre a questão da eventual influência da religião na política, procurando mostrar como foi diferenciado o discurso externado por um grupo parlamentar que ganha força eleitoral na política partidária brasileira e que apela para uma identidade religiosa, ou seja, a Bancada Evangélica. Afinal, se a porcentagem de votos a favor do impeachment foi de $93,8 \%$ entre os evangélicos e de $67,7 \%$ entre os não evangélicos, que diferenças se mostrariam nas justificativas desses votos? Alguma diferença substantiva seria de se esperar entre esses dois grupos em termos de valores e de orientação para a política.

Nessa busca, a religião deu algumas mostras de seu novo papel de ator político, mas que evidentemente nada tem a ver com o antigo poder que a Igreja Católica detinha, até pouco tempo atrás, na legitimação e no controle da sociedade, bem como de suas instituiçôes (Pierucci, 2008a). Nesse novo momento de afirmação política da religião evangélica - em que a votação na Câmara Federal funcionou como uma espécie de vitrina nacional -, seus representantes se mostraram acenando em coro numa mesma direção. $\mathrm{O}$ voto contra Dilma dado pelos membros da Bancada Evangélica só não atingiu os $100 \%$ por causa da presença na fileira evangélica de cinco deputados que votaram a favor de Dilma, fosse por sua filiaçáo aos partidos que a apoiaram ou por compromisso político pessoal. 
Os dados apresentados permitem concluir que a Bancada Evangélica, em comparação com o grupo não evangélico, votou mais fortemente apoiada em justificativas que se mostraram afinadas menos com valores democráticos e mais com o universo da tradição. Seguem, em geral, a mesma linha dos não evangélicos que votaram a favor do impeachment, mas manifestam seus argumentos com maior peso, o que os distingue no conjunto dos deputados como grupo diferenciado pela identidade religiosa. Até recentemente distanciados de forma significativa, em sua maioria, da vida política do país, o breve tempo de sua inclusão na política partidária pode não ter ainda propiciado aos representantes evangélicos o cultivo mais acurado de valores da democracia, que em muitas circunstâncias podem se chocar com os da religião.

De toda forma, os dados aqui expostos respaldam a interpretação de que a incursão dos evangélicos na política está ligada, acima de tudo, à defesa da tradição. É isso que a legitima junto aos fiéis e é por isso que os seus discursos se voltam, a todo momento, à reafirmação da defesa dos valores tradicionais. Num dos momentos de maior exposição midiática do Congresso, não teria por que ser diferente. Ora, se é a defesa da tradição que está em jogo, trata-se de uma pauta eminentemente conservadora, posto que se procura barrar, via intervenção política, e não mais apenas no âmbito cultural e interpessoal, o avanço de qualquer proposta liberalizante, progressista, condizente com mudanças sociais e culturais em curso no mundo moderno. Essa é a cola que une os evangélicos das mais diferentes denominações na arena política, já que fora dali as disputas entre diferentes igrejas e lideranças são das mais obstinadas.

Por isso, e por mais que acordos e conchavos dos mais diversos possam estar por trás do voto evangélico a favor do impeachment, sua justificativa pública tem de passar, inevitavelmente, pela defesa da tradição. Ou seja, os favores e benefícios obtidos em troca do voto podem até ter nome próprio, mas sua justificativa pública, sua legitimidade, tem de ser obtida em nome do pai: Deus, a igreja, a família, o país, seu lugar e aqueles que o habitam.

\section{Notas}

1 O número de deputados da Bancada Evangélica muda com as frequentes substituiçóes de deputados que ocupam postos executivos ou se licenciam por razôes diversas. Nem sempre o substituto tem a mesma religião do substituído. Sobre a composiçấo da Bancada Evangélica, ver inicialmente Diap (2014), que fornece a lista de composição das diferentes frentes parlamentares, considerando os parlamentares do início da legislatura. Para a presente pesquisa, fontes complementares, adiante especificadas, permitiram atualizar a lista na data da votação da admissibilidade do impeachment.

2 Não é possível aqui oferecer uma história, mesmo que concisa, dos movimentos católicos pós-conciliares ou da efervescência da expansão evangélica e suas transformaçóes sem deixar lacunas e privilegiar aspectos do extenso debate sobre mudanças religiosas no Brasil recente. Difícil igualmente dar conta de toda a discussão que vem buscando compreender a participação de agentes religiosos na política. Um bom ponto de partida, para os interessados, pode ser encontrado em textos que compóem as coletâneas organizadas por Burity e Machado (2006) e Teixeira e Menezes (2013). Sobre o também controverso conceito de secularizaçáo, que lastreia o presente texto, recomenda-se a consulta a Pierucci (1998; 2008a), Prandi (1975; 2008) e Pierucci e Prandi (1996).

\section{BIBLIOGRAFIA}

BRUCE, Steve. (2011), "Defining religion: a practical response". International Review of Sociology, 21 (1): 107-120.

BURITY, Joanildo \& MACHADO, Maria das Dores Campos (orgs.). (2006), Os votos de Deus: evangélicos, politica e eleiçóes no Brasil. Recife, Massangana.

CAMARGO, Candido Procopio Ferreira de. (1971), Igreja e desenvolvimento. São Paulo, Cebrap/Editora Brasileira de Ciências.

CAMARGO, Candido Procopio Ferreira de et al. (1973), Católicos, protestantes, espiritas. Petrópolis (RJ), Vozes.

CAMPOS, Leonildo Silveira. (2006), "De políticas de Cristo: uma análise do comportamento político de protestantes históricos e pentecostais no Brasil”, in Joanildo Burity e Maria das Do- 
res Campos Machado (orgs.), Os votos de Deus: evangélicos, politica e eleiçóes no Brasil, pp. 2990. Recife, Massangana.

CARNEIRO, João Luiz. (2014), Religióes afro-brasileiras. Petrópolis (RJ), Vozes.

CARRANZA, Brenda. (2000), Renovação carismática católica. Aparecida (SP), Santuário.

CASANOVA, José. (2010), "O problema da religião e as ansiedades da democracia secular europeia". Rever: Revista de Estudos da Religiāo, 10 (4): 1-16. COSTA, Guilherme Borges Ferreira. (2014), Ortodoxia em dois tempos: do clericalismo político à secularização estatal. Dissertação de mestrado. São Paulo, FFLCH/USP.

DIAP. (2014), Radiografia do novo Congresso: legislatura 2015-2019. Brasília, Diap.

FERNANDES, Marcella \& CASTRO, Grasielle. (2016), "Bancada Evangélica aposta em governo Temer para avançar em pautas conservadoras". Huff Post Brasil [online]. Disponível em www.huffpostbrasil.com/2016/04/17/ bancada-evangelica-temer_n_9712304.html, consultado em 29/6/2016.

HERVIEU-LÉGER, Danièle. (2003), “Quand la nature n'est plus un ordre, in ___ Catholicisme, la fin d'un monde, pp. 215-248. Paris, Bayard.

JANONI, Alessandro. (2016), "Votação revela mais sobre eleitores do que sobre deputados". Folha de S. Paulo, 25 jul. Disponível em www1.folha. uol.com.br/poder/2016/04/1762545-votacao-revela-mais-sobre-eleitores-do-que-sobre-deputados.shtml, consultado em 29/6/2016.

MACHADO, Maria das Dores Campos \& BURITY, Joanildo. (2014), "A ascensão política dos pentecostais no Brasil na avaliação de líderes religiosos". Dados, 57 (3): 601-631.

MARIANO, Ricardo. (1999), "O futuro não será protestante”. Ciências Sociais e Religiāo, 1: 89114.

(2005), Neopentecostais: sociologia do novo pentecostalismo no Brasil. 2. ed. São Paulo, Loyola.

. (2011), "Laicidade à brasileira: católicos, pentecostais e laicos em disputa na esfera pública”. Civitas: Revista de Ciências Sociais, 11 (2): $238-258$.
MCDONALD, R. P. (1985), Factor analysis and related methods. Hillsdale, Lawrence Erlbaum Associates.

MENDONÇA, Antônio Gouvêa. (2008), "Protestantismo brasileiro, uma breve interpretação histórica”, in Beatriz Muniz de Souza e Luís Mauro Sá Martino (orgs.), Sociologia da religiáo e mudança social, pp. 49-79, São Paulo, Paulus.

NORRIS, Pippa \& INGLEHART, Ronald. (2006), "Sellers or buyers in religious markets? The supply and demand of religion". The Hedgehog Review: After Secularization, 8 (1-2): 69-92.

. (2007), "Uneven secularization in the United States and Western Europe", in Thomas Banchoff (org.), Democracy and the new religious pluralism, pp. 31-58, Oxford, Oxford University Press.

ORO, Ari Pedro. (2006), "A Igreja Universal e a política”, in Joanildo Burity e Maria das Dores Campos Machado (orgs.), Os votos de Deus: evangélicos, política e eleiçôes no Brasil, pp. 119148, Recife, Massangana.

PIERUCCI, Antônio Flávio. (1996), "Representantes de Deus em Brasília: a bancada evangélica na Constituinte”, in Antônio Flávio Pierucci e Reginaldo Prandi, A realidade social das religióes no Brasil: religiāo, sociedade e politica, pp. 163-191, São Paulo, Hucitec.

. (1998), "Secularização em Max Weber: da contemporânea serventia de voltarmos a acessar aquele velho sentido". Revista Brasileira de Ciências Sociais, 13 (37): 43-73.

. (2008a), "Secularização e declínio do catolicismo", in Beatriz Muniz de Souza e Luís Mauro Sá Martino (orgs.), Sociologia da religião e mudança social, São Paulo, Paulus.

. (2008b), "De olho na modernidade religiosa”. Tempo Social, 20 (2): 9-16.

. (2013), "O crescimento da liberdade religiosa e o declínio da religiâo tradicional: a propósito do Censo de 2010”, in Faustino Teixeira e Renata Menezes (orgs.), Religióes em movimento: o Censo de 2010, pp. 49-61, Petrópolis, Vozes.

PIERUCCI, Antônio Flávio \& MARIANO, Ricardo. (1996), "O envolvimento pentecostal na eleição de Collor”, in Antônio Flávio Pierucci e 
Reginaldo Prandi, A realidade social das religióes no Brasil: religiáo, sociedade e política, São Paulo, Hucitec.

PIERUCCI, Antônio Flávio \& PRANDI, Reginaldo. (1996), A realidade social das religióes no Brasil: religião, sociedade e política. São Paulo, Hucitec.

PRANDI, Reginaldo. (1975), Catolicismo e familia: transformação de uma ideologia. São Paulo, Brasiliense.

(1996), "Religião paga, conversão e serviço", in Antônio Flávio Pierucci e Reginaldo Prandi, A realidade social das religióes no Brasil: religiáo, sociedade e política, São Paulo, Hucitec.

. (1998), Um sopro do Espírito. São Paulo, Edusp.

. (2008), "Religions and cultures: religious dynamics in Latin America". Social Compass, 55 (3): 265-275.

. (2012), Os mortos e os vivos: uma introdução ao espiritismo. São Paulo, Três Estrelas.

PRANDI, Reginaldo \& PAULINO, Mauro. (2015), "A política evangélica: em que temas ela é mais conservadora". Folha de S. Paulo, Ilustríssima, p. 3, 15 nov.

PRANDI, Reginaldo \& SANTOS, Renan William dos. (2015), "Mudança religiosa na sociedade secularizada: o Brasil 50 anos após o Concílio Vaticano II". Contemporânea, 5 (2): 351-379.

. (2017), "Quem tem medo da bancada evangélica? Posições sobre moralidade e política no eleitorado brasileiro, no Congresso Nacional e na bancada evangélica”. Tempo Social, 29 (2): 173-200.

ROSADO-NUNES, Maria José. (2004), "O catolicismo sob o escrutínio da modernidade", in Beatriz Muniz de Souza e Luís Mauro Sá Martino (orgs.), Sociologia da religiáo e mudança social, São Paulo, Paulus.

STEIL, Carlos Alberto (2001), "Eleições, voto e instituição religiosa”. Debates do NER, 2 (3): 73-83.

TEIXEIRA, Faustino \& MENEZES, Renata (orgs.). (2013), Religióes em movimento: o censo de 2010. Petrópolis (RJ), Vozes.
WEBER, Max. (1991), "A dominação tradicional”, in , Economia e sociedade. vol. 1. Brasília, Editora UnB.. . (2004), A ética protestante e o "espirito" do capitalismo. São Paulo, Companhia das Letras, 2004. 


\section{EM NOME DO PAI: JUSTIFICATIVAS DO VOTO DOS DEPUTADOS FEDERAIS EVANGÉLICOS E NÂO EVANGÉLICOS NA ABERTURA DO IMPEACHMENT DE DILMA ROUSSEFF}

\section{Reginaldo Prandi e João Luiz Carneiro}

Palavras-chave: Votação do impeachment; Razóes do voto; Impeachment da presidente Rousseff; Evangélicos na política; Bancada Evangélica.

$\mathrm{O}$ artigo analisa as justificativas dos deputados federais ao voto a favor ou contra a abertura do processo de impeachment da presidente Dilma Rousseff e foca as diferenças entre os motivos apresentados pelos membros da Bancada Evangélica em comparaçáo com os dos demais deputados da Câmara dos Deputados. A porcentagem de votos a favor do impeachment foi de $93,8 \%$ entre os evangélicos e de $67,7 \%$ entre os não evangélicos. A pesquisa procurou mostrar que outras diferenças se revelariam nas justificativas desses votos. Partindo das notas taquigráficas da sessão de votação, foram identificadas 26 diferentes classes de razóes e motivos. Os autores esperam que a presente análise permita lançar alguma nova luz sobre a participação dos evangélicos na política partidária brasileira. Os dados trabalhados permitem concluir, entre outros achados, que a Bancada Evangélica votou apoiada em justificativas que se mostraram pertencentes menos ao âmbito dos valores democráticos e mais ao universo da tradição.
IN THE NAME OF THE FATHER:
JUSTIFICATIONS FOR THE VOTE
OF EVANGELICAL AND NON-EVAN-
GELICAL REPRESENTATIVES IN
THE OPENING OF THE IMPEACH-
MENT OF DILMA ROUSSEFF

Reginaldo Prandi e João Luiz Carneiro

Keywords: The impeachment vote; Reasons for voting; Impeachment of President Rousseff; Evangelicals in politics; Bancada Evangélica.

The article examines the justifications of the federal representatives to their votes in favor or against the opening of impeachment of President Dilma Rousseff and focuses on the differences between the reasons given by members of the Bancada Evangélica in comparison with the other members of the Câmara dos Deputados. The percentage of votes in favor of impeachment was $93.8 \%$ among evangelicals and $67.7 \%$ among non-evangelicals. The research sought to show that other differences would be revealed by the justifications of those votes. Starting from shorthand notes of the voting session, 26 different classes of reasons and motives were identified. The authors hope that the presented analysis of these data enable shed some new light on the involvement of Evangelicals in Brazilian politics. The research indicates, among other findings, that the Evangelical Caucus voted supported by justifications that belonged mostly to the universe of tradition instead of the democratic universe.

\section{AU NOM DU PÈRE: JUSTIFICATIONS DES VOTES DES DÉPUTÉS FÉDÉRAUX ÉVANGÉLIQUES ET DES NON- ÉVANGÉLIQUES À L'OUVERTURE DE LA PROCÉDURE DE L'IMPEACHMENT DE DILMA ROUSSEFF}

Reginaldo Prandi et João Luiz Carneiro

Mots-clés: Vote de l'impeachment; Raisons du vote; Destitution de la Présidente Rousseff; Évangéliques en politique; Front évangélique.

L'article examine les justifications des députés fédéraux au vote en faveur ou contre l'ouverture de la procédure de l'impeachment de la Présidente Dilma Rousseff et met l'accent sur les différences entre les raisons invoquées par les membres du Front Évangélique en comparaison avec les autres députés de la Chambre des Députés. Le pourcentage de votes en faveur de l'impeachment a été de 93,8\% parmi les évangéliques et de $67,7 \%$ parmi les non-évangéliques. Cette recherche a tenté de démontrer que d'autres différences se révéleraient dans les justifications de ces votes. À partir de notes sténographiques de la séance des votes, 26 différentes catégories de raisons et motivations ont été identifiées. Les auteurs espèrent que cette analyse permettra de lancer une lumière nouvelle sur la participation des évangéliques dans la politique brésilienne. Les données traitées permettent, parmi d'autres, de conclure que le Front Évangélique a voté appuyée par des justifications qui appartenaient en moindre mesure au cadre des valeurs démocratiques et davantage à l'univers de la tradition. 